\title{
Impact of Demonetization on Supply Chain in Indian Context
}

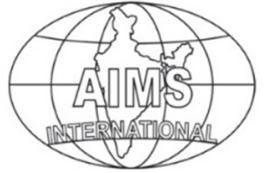

DOI: $10.26573 / 2018.12 .1 .1$

Volume 12, Number 1

January 2018, pp. 1-10

\author{
Chandra K. Jaggi \\ Reena Jain \\ Mona Verma \\ University of Delhi \\ (ckjaggi@yahoo.com) \\ (reenajain1910@yahoo.com) \\ (monavermag@sscbsdu.ac.in)
}

Supply chain management is the flow of materials, information, and finances from one level to another. It is said to be effective if right information can be traversed in both the directions in right time. If this information is distorted at any level of supply chain it is called bullwhip effect. The bullwhip effect always remains a matter of concern in supply chain and demonetization has amplified it many fold. Not long ago, Demonetization in India had not only affected the supply chain adversely but also scarcity of cash had imposed a threat on day to day business. In this paper, an attempt has been made to establish that the demonetization can be one of the major causes of bullwhip effect. With the help of data collected from RBI reports, a complete analysis has been done in support of this very fact. Moreover, some remedies are suggested to overcome the said problem in supply chain due to demonetization.

Keywords: Supply Chain, Demonetization, Digitalization, Bullwhip Effect, Gross Value Added (GVA), Electronic Money

\section{Introduction}

A supply chain is a system of organizations, people, activities, information, and resources involved in moving a product or service from supplier to customer. Supply chain activities involve the transformation of natural resources, raw materials, and components into a finished product that is delivered to the end customer. In sophisticated supply chain systems, used products may re-enter the supply chain at any point where residual value is recyclable.

A supply chain consists of multiple stages of operations, connected by three types of "flow" i.e. information flow, material flow and financial flow. Information flow refers to informational interactions between supply chain stages, such as information regarding orders and requests for supplies and products. Material flow refers to the flow of supplies and products that are delivered in response to orders and requests. Financial flow includes all of the financial transactions that are associated with supply chain operations, which represents the core economics of supply chain. The disturbance in any of these flows can pose a threat for the smooth functioning of supply chain. Any variability in sales and demand, as one move from lower to higher level of supply chain is termed as bullwhip effect (Figure1).

In literature, the researchers have discussed four causes of bullwhip effect, (Lee et al. 1997 (a)). 


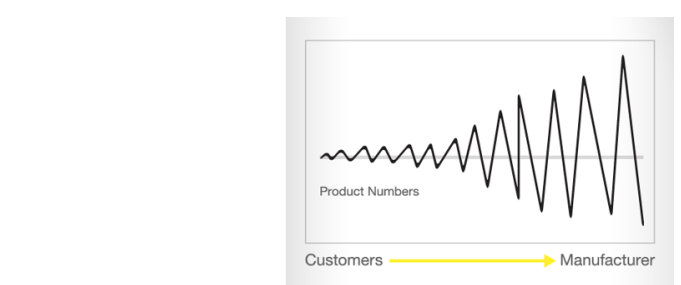

Figure 1 Bullwhip effect www.aalhysterforklifts.com.au/uploads/blog/bullwhip_effect_diagram.png

Demand Signal Processing: The inaccurate forecast of demand at any level of supply chain can create variability between demand and sales.

Order Batching: The ordering policy used by members of supply chain may vary the demand. For example, if one is ordering in batch of 25 , then to satisfy the demand of 30 one has to order two lots of 25 each, i.e. 50 units, by which the demand gets inflated by $67 \%$ at one level of supply chain.

Price Variations: Discounts, promotional schemes, off seasonal sales and many other such policies provoke the customers to buy more than the requirement and can become a cause of variation in sales.

Rationing and Shortage Gaming: Rationing of the products by the manufacturer to retailers according to some predefined policies, due to some limitations in production, can cause variation in demand.

Bullwhip effect was firstly observed by Forrester in 1961 (Forrester, 1961). (Metters, 1997) stated the two main reasons of bullwhip effect as seasonal demand and errors in forecasting of demand. (Kelle, et al., 1999) described the effect of order batching on demand and hence on supply chain. (Jaggi, et al., 2010) explored the cause of bullwhip effect due to rationing and shortage gaming. Ample research has been done related to the already declared causes of bullwhip effect (Kaplan, 1969, Nahmias, 1981, Lee et al., 1997(a), Lee et al., 1997(b), Cachon, 1999(a), Cachon, 1999(b), Chopra \& Meindl, 2006).

Since midnight of 8th November, 2016, the Indian government decided to demonetize the 500/- and 1000/- rupee notes, the two biggest denomination notes. These notes accounted for $86 \%$ of the country's cash supply (Jan, 2017). The government's goal was to eradicate counterfeit currency, fight tax evasion, eliminate black money received from money laundering and terrorist financing activities, and promote a cashless economy. This act was termed as demonetization which adversely affected the supply chain, mainly the retail industry due to liquidity crunch. The reason was distortion in financial flow due to cash crunch caused by demonetization of high denomination currency. The scarcity of finances at any level of supply chain may force the members of the supply chain to change the order size that may increase the variability between demand and sales causing bullwhip effect.

Nowadays the market has taken entirely a new shape. It has been changed from manufacturer oriented to consumer oriented completely. Any cause which can change the behavior of consumer will definitely affect the supply chain. As the Indian retail industry generates a lot of cash transactions, a reduction in sales was 
majorly felt by small traders and the unorganized retail segments for the two quarters following the demonetization. However in some sectors its effect can be seen even after an year. The researchers (Shirley, 2017) and (Mali, 2016) have talked about impact of demonetization in India in economic context, but its impact on supply chain has not been explored yet. Moreover, in the context of supply chain it is yet to be evolved how demonetization can emerge as the cause of bullwhip effect. In the present paper, an attempt has been made to show how demonetization can be considered as one of the major causes of bullwhip effect.

During uncertain times, a good demand plan and supply chain strategy is the cornerstone that can deliver both cost and asset turnover (Mar, 2016). Effect of demonetization on the construction sector and some of the labor intensive manufacturing sectors such as textiles, leather, gems and jewels and the transportation sector cannot be ignored. The loss of wage income for workers is also expected to have caused a drag on consumption demand. In good economy, one could look to sales and marketing and follow a top line growth strategy effectively, but when the sales fall due to poor economy conditions, there is only one thing that works best i.e. a laser sharp focus on cash, cost, and efficiency in a supply chain.

This paper is organized in six sections. First section gives introduction along with literature review. Second section is the objective of the paper, which is followed by research methodology in section 3. Section 4 has been devoted to comprehensive data analysis with the real authentic data from RBI report. Finally, the findings have been summarized in section 5 , followed by references in section 6 .

\section{Objective}

The causes of bullwhip effect are not confined to what the researchers have elaborated till now. With the changing market conditions, new causes have been evolving due to variability in pattern of supply and demand. The objective of the paper is to establish how demonetization can be considered as a new cause of bullwhip effect.

\section{Research Methodology}

The present paper is based on secondary research. Ample literature has been explored to gather the knowledge of bullwhip effect and supply chain that can be used for further analysis. The secondary data has been collected from RBI report (2017). The anecdotes related to demonetization have been taken from internet and newspapers. Data from RBI report along with the knowledge from literature has been used in order to establish our objective.

\section{Data Analysis}

Supply chain is the foundational element that can make or break an organization during downturn in the economy. For example, improvements in forecast accuracy can enable efficiencies and responsiveness to market conditions. Since accurate demand forecasts facilitate better planning which results in lower inventory levels, higher inventory turnover and eventually improving customer service levels.

In past few months, supply chain in India was dealing with variability between supply and demand. Due to demonetization, all the sales forecast performed by industries for the period Dec 2016-Jan 2017 failed because of the sharp decline in 
sales. Traditionally, India had been a cash sensitive market. Due to cash crunch, the decline in sales eventually affected the production. Moreover, the impact was not limited to sales and production, but it also resulted in increased inventory carrying cost because of hindered movement of stock in the supply chain. In fact, demonetization has left its impact in all the sectors of the economy as the cash crunch has broken down the supply chain in totality. Further, the consumers dealing with less of cash were spending only on the most essential commodities. Moreover, to neutralize the impact of demonetization, the distributors started offering discounts to their downstream member i.e. wholesalers and retailers in order to recover the amount blocked in their stock. Furthermore, the impact of demonetization on logistics cannot be neglected. Inability of the distributors to pay in cash resulted in non-movement of trucks, idle labors without wages which had drastically trembled the supply chain. Such situation can be illustrated with the help of anecdotes (Nov, 2016) namely

- The managing director of Britannia Industries Ltd, Mr. Varun Berry said, "The best are probably down by $40 \%$, the worst are down by $70-75 \%$. Outlet sales are down and hence the reorders are down".

- P.C. Musthafa, co-founder, id Fresh Food (India) Pvt. Ltd, which supplies six million parathas and batter for a million idlies daily said, "There has been a big impact...(even in) chain stores. Traders are taking in stock, but consumers do not have money to buy the product."

- According to Jitendra Aggarwal, a Nashik-based stockiest and distributor for companies such as Dabur India Ltd. and Marico Ltd., "Our business had reduced by $60-70 \%$ because of cash crunch".

- Praveen Khandelwal, the Secretary General of the Confederation of All India Traders, said, "The lack of cash flow in the markets is equally affecting traders and transport sectors as well, since both these businesses totally function on cash".

- Transporters said "most of us owning trucks, canters and other medium commercial vehicles are sitting at home as we don't have enough cash to use during a long-route journey".

Further these anecdotes can be established through data collected from RBI report (Table 1(2017)). This report is year-on-year growth basis, in terms of GVA. Yearon-year is a statistical term used for comparing the value of any statistic for one period with the value of same statistic for same period of previous year. This period can be a day, a week, a month, a quarter or a year. In economic terms, GVA is defined as the measure of the value of goods and services produced in an industry or sector of an economy. According to national accounts, GVA is the difference of output and intermediate consumption. According to the report, the GVA growth for 2016-17 was estimated as 7.6 per cent before demonetization, but only 6.9 per cent was realized in Jan'17. A significant decrease in GVA growth was experienced in Quater3 (Q3) of 2016. The reason was the limited access to currency as a power of exchange for materializing transactions in the market. This crash resulted from

- Decrease in demand due to shortage of cash to make payments

- Interruption in production activity, especially in those sectors where wages are paid in cash. 
The construction sector and some of the labor intensive manufacturing sectors like textiles, leather, gems and jewel and the transportation sector were affected a lot because of demonetization. The loss of wage income for workers was responsible for drag on consumption demand.

Moreover, in Table 1, the Purchasing Managers' Index (PMI) is used to indicate economic progress in manufacturing and service sector. The PMI is based on five major indicators: new orders, inventory levels, production, supplier deliveries and the employment environment. A PMI of more than 50 represents expansion of the sector when compared to the previous month. A PMI under 50 represents a contraction.

Table 1 Lead Indicators of Economic Activity (Year-on-Year Growth in Per Cent\#)

\begin{tabular}{|l|c|c|c|c|c|c|}
\hline \multicolumn{1}{|c|}{ Sectoral Indicators } & Apr-Oct 16 & Oct-16 & Nov-16 & Dec-16 & Jan-17 & Feb-17 \\
\hline PMI Manufacturing & 52 & 54.4 & 52.3 & 49.6 & 50.4 & 50.7 \\
\hline PMI services & 52.6 & 54.5 & 46.7 & 46.8 & 48.7 & 50.3 \\
\hline Automobile sales & 15.0 & 8.1 & -5.5 & -18.7 & -4.7 & 0.9 \\
\hline Commercial vehicles sales & 6.9 & 11.9 & -11.6 & -5.1 & -0.7 & 7.3 \\
\hline Passenger vehicle sales & 11.0 & 4.5 & 1.8 & -1.4 & 14.4 & 9.0 \\
\hline Three wheelers sales & 11.8 & 4.4 & -25.9 & -36.2 & -28.2 & -21.4 \\
\hline Two wheelers sales & 16.0 & 8.7 & -5.9 & -22.0 & -7.4 & 0 \\
\hline Cargo handled at major ports & 6.3 & 13.2 & 10.2 & 12.9 & 3.6 & N.A. \\
\hline Cement production & 4.8 & 6.2 & 0.5 & -8.7 & -13.3 & N.A. \\
\hline
\end{tabular}

${ }^{\#}$ RBI, Ministry of Agriculture, CSO, SIAM, IRDA, CMIE

It is evident from Table 1 that demonetization has adverse impact on PMI manufacturing and services. The sales of automobile contracted in all the months from November to January 2017 as compared to previous year, though it returned to expansion mode by 0.9 per cent in February. Sales of commercial vehicles decreased by 11.6 per cent in November, 5.1 per cent in December 2016, and 0.7 per cent in January 2017, whereas before demonetization this sector was expanding because of an average growth of 6.9 per cent during April-October 2016. In February 2017, it returned to expansion. Growth in sales of passenger vehicles also dropped down to 1.8 per cent in November 2016 and further decreased by 1.4 per cent in December 2016, but rebounded sharply to 14.4 per cent in January 2017 and expanded by 9 per cent in February 2017 as compared to corresponding months of previous year. Similar results can be interpreted for other sectors as well.

Not only economic activity indicators, but consumer durable segments also get affected by demonetization. In Table 2 growth of items under this segment has been established quantitatively. Growth with respect to value and volume, a month before and a month after demonetization is expressed.

The data values under October and November month clearly shows the change in sales with respect to value as well as volume. The sales of microwave were escalated by $90.6 \%$ in October 2016 as compared to Oct 2015. The increase in revenue was also approximately same i.e., 90.7\%, which shows that increase in revenue was just because of sales, but due to impact of demonetization market collapsed in Nov, 
2016. Sales as well as revenue have fallen down in the tune of $53 \%$. Similarly one can interpret the result of other consumer durable items. These results have been depicted graphically in Figure 2.

Table 2 Growth in Consumer Durable Segments (Year-on-Year Growth in Per Cent*)

\begin{tabular}{|l|c|c|c|c|}
\hline \multicolumn{1}{|c|}{ (In Per cent) } & \multicolumn{2}{c|}{ Volume Growth } & \multicolumn{2}{c|}{ Value Growth } \\
\hline Category & Oct 2016 & Nov 2016 & Oct 2016 & Nov 2016 \\
\hline Microwave & 90.6 & -53.0 & 90.7 & -51.5 \\
\hline Refrigerator & 74.0 & -41.2 & 73.4 & -40.3 \\
\hline Washing Machine & 116.7 & -31.7 & 113.1 & -34.4 \\
\hline Flat Panel TV & 94.7 & -30.4 & 99.4 & -26.6 \\
\hline
\end{tabular}

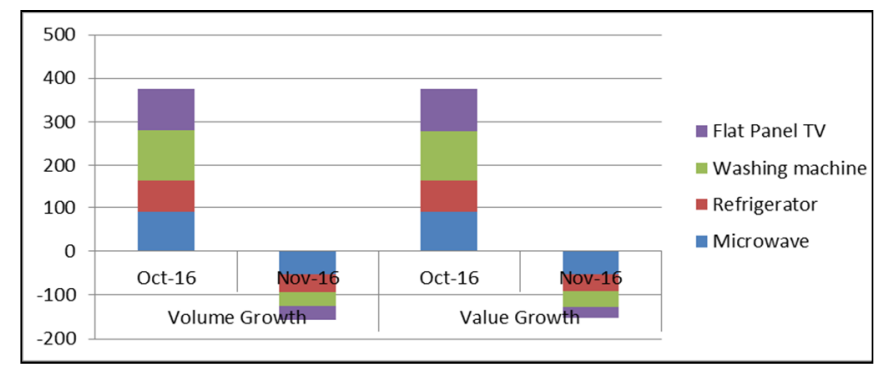

Figure 2 Graphical Representation of Drift in Value and Volume of Consumer Durable Items

Figure 2 infers that, demonetization had negative impact on sales and hence on revenue. To overcome the adverse impact of it on supply chain, one had to adopt modern technology such as e-wallet, plastic money or any other digital mode of transaction. The Government of India and the RBI have initiated a series of measures, some of which are temporary, to promote movement from cash to noncash modes of transactions. This includes:

- Introduction of half hourly settlement of National Electronic Funds Transfer (NEFT).

- Waiver of charges for small value transactions under Immediate Payment Service (IMPS), Unified Payment Interface (UPI) and Unstructured Supplementary Service Data (USSD).

- Reduction in the Merchant Discount Rate (MDR) and Point Of Sale (POS) fees

- Monetary incentives in the form of discounts and prizes.

- Service tax relief on MDR for small transactions.

The government has also announced that it would ensure that transactions fee or MDR charges associated with payment through digital means shall not be passed on to consumers. These measures encouraged migration of consumers from cash to digital modes of payments. Other than debit and credit cards, digital wallets were also promoted. Many digital wallet companies like Paytm, Rupay, Mobikwik, Payzapp etc. has been promoting their business by offering discounts and cash backs. 
For the purpose of quantifying this data, Table 3 (2017) is presented. It shows drift from cash transactions to non-cash transactions.

Table 3 Growth in Selected Electronic Modes of Payments (Year-on-Year Growth in Per Cent $\left.{ }^{\circledR}\right)$

\begin{tabular}{|l|c|c|c|c|c|c|}
\hline Category & & Oct-2016 & Nov-2016 & Dec-2016 & Jan-2017 & Feb-2017 \\
\hline \multirow{2}{*}{ NEFT } & Volume & 16.2 & 23.3 & 39.0 & 38.0 & 34.5 \\
\cline { 2 - 7 } & Value & 37.6 & 38.3 & 40.8 & 60.2 & 49.5 \\
\hline \multirow{2}{*}{ CTS } & Volume & -1.1 & 23.0 & 58.4 & 52.7 & 20.2 \\
\cline { 2 - 7 } & Value & 2.9 & 8.6 & 13.0 & 19.3 & 0.8 \\
\hline \multirow{2}{*}{ IMPS } & Volume & 116.7 & 89.6 & 157.2 & 177.7 & 150.4 \\
\cline { 2 - 7 } & Value & 150.7 & 135.9 & 186.6 & 196.7 & 184.2 \\
\hline \multirow{2}{*}{ NACH } & Volume & 53.0 & 30.8 & 58.3 & 19.8 & -0.9 \\
\cline { 2 - 7 } & Value & 89.8 & 76.3 & 116.7 & 22.8 & 54.2 \\
\hline
\end{tabular}

${ }^{(a}$ RBI Bulletins and Press Releases on Electronic Payment Systems - Representative Data

Further, Table 3 is also interpreted pictorially as shown in Figure 3. The graph clearly represents the growth in digital mode of payment with respect to value and volume. As per statistics, the digital activities were high in October 2016, i.e. just before demonetization, probably because of festive season, but a decline was seen in initial weeks, just after the demonetization, which had deferred the sales pattern and given rise to bullwhip effect. People were busy in depositing and exchanging old currency. However, in December 2016 transactions got increased. To meet the problem of cash crunch, people started using digital mode of payment even for very small amounts. The pace of growth got moderated somewhat in February 2017. Gradually, digitalization reduced the impact of demonetization and as a result, bullwhip effect was also reduced.

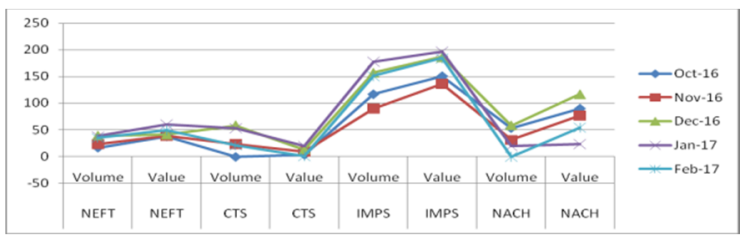

Figure 3 Graphical Representation of Drift in Value and Volume of Digital Mode of Payments

It is apparent from above that digitalization can reduce bullwhip effect caused as a result of demonetization. In other words, one can conclude that digitalization can serve as a remedy to demonetization.

\section{Managerial Implications}

Demonetization will always remain a topic of interest for managers. Since demonetization is not only a cause or a factor to affect the managerial decisions, but also has brought the revolution in business. Moreover, it has affected all types of business establishments. Further, one can interpret demonetization as deflationary 
situation, means too little money chasing too many goods. Keeping all these things in mind, the present paper establishes a relationship between demonetization and bullwhip effect, i.e. variability between supply and demand. Demonetization had elevated this variability to many folds. In order to reduce this variability, digital mode of transactions were brought into action to the larger extent. Eventually, cashless economy should be encouraged to overcome such situations in future.

\section{Conclusion}

This paper provides empirical justification in favor of objective of the paper. Demonetization is an activity, which had affected ordering policy, demand forecasting, production, price variations and many more responsible for causing bullwhip effect. It had created a never-ever type situation when product is available, purchasing capacity is present but the means of transaction i.e. currency is lacking. This situation had elaborated the bullwhip effect many fold. The results and analysis of data has shown that all the four defined causes of bullwhip effect would be amplified in a situation like demonetization. Demonetization is an act of Government to improve the economy of country, i.e. economic reform and it is not a situation which cannot occur again. We have proved quantitatively that digitalization can serve as a remedy to fight with situation like demonetization.

\section{Acknowledgement}

We would like to express our sincerest thanks to the Editor and anonymous reviewers for their constructive and valuable comments in improving the manuscript.

\section{References}

1. Cachon G.P. \& Lariviere, M.A., 'Capacity choice and allocation: Strategic behavior and supply chain performance', Management Science, 45, 1999(a) 1091-1108.

2. Cachon G.P. \& Lariviere, M.A., 'An equilibrium analysis of linear and proportional allocation of scarce capacity', IIE Transactions, 31, 1999(b) 835849

3. Chopra, S. \& Meindl, P, 'Supply Chain management: Strategy, planning and operation', Pearson Prentice Hall, Upper Saddle River, 2006.

4. Forrester, J. 'Industrial Dynamics', MIT Press, Wiley, New York, 1961.

5. Jaggi, C.K., Aggarwal , K.K, \& Verma Mona, 'Allocation Game in a single period Supply Chain Model', Revista Investigacion Operacional ,Vol., 31 , No. 3, 258-267, 2010

6. Kaplan A., 'Stock Rationing', Management Science, 15, 1969, 260-267.

7. Kelle, P., \& Milne, A., 'The Effect of (s, S) ordering Policy on Supply Chain', Production Economics, Vol.59, 1999, 113-122.

8. Lee, H. L., Padmanabhan, V. \& Whang, S., 'Information Distortion in Supply Chain: The Bullwhip Effect', Management Science, Vol. 43(4), 1997(a), 546558.

9. Lee, H. L., Padmanabhan, V. \& Whang, S., 'The Bullwhip effect in supply chains', Sloan Management review' 38, 1997(b), 93-102

10. 'Macroeconomic Impact of Demonetisation - A Preliminary Assessment', Reserve Bank of India March 10, 2017. 
11. Mali Vedashree, 'Demonetization: A step towards modified India' International Journal of Commerce and Management Research, Volume 2, Issue 12, December 2016, 35-36.

12. Metters, R., 'Quantifying the Bullwhip Effect in Supply Chain', Operations Management, Vol. 15, 1997, 89-100.

13. Nahmias, S. \& Demmy, W. Steven, 'Operating Characteristics of an inventory system with Rationing', Management Science, 27, 1981, 1221-1235.

14. Shirley Jasmine,' Impact of Demonetization in India, 'International Journal of Trend in Research and Development (IJTRD), ISSN: 2394-9333, February 2017, Special Issue.

15. https://blog.arkieva.com/supply-chain-planning-and-an-uncertain-economy/ (Mar, 2016).

16. http://economictimes.indiatimes.com/demonetisation-old-rs-500-and-rs-1000notes-now-illegal-news-reports-and-developments/liveblog $/ 55396555 . \mathrm{cms}$ Jan, 2017).

17. http://timesofindia.indiatimes.com/city/noida/80-of-transporters-go-off-roadsfollowing-demonetization-of-Rs-500-and-1000/articleshow/55422389.cms (14 Nov, 2016).

18. http://www.livemint.com/Industry/30rv45zcmeFG2nwfbldhVM/Note-ban-hitsconsumer-packaged-goods-sales-supply-chain.html (Nov 2016).

\section{About Our Authors}

Chandra K. Jaggi Professor, Department of Operational Research, University of Delhi, Delhi, India. In the year $2017 \mathrm{He}$ was honored with International Best Researcher Award 2017; Certificate of Excellence "BHARAT VIKAS AWARD"; "Best Teacher Award". He was awarded "IEOM Outstanding Service Award" by IEOM Society, USA in 2016.Certificate of Excellence in $2^{\text {nd }}$ Academic Brilliance Award 2014.Certificate for his Exceptional Contributions in the field of Inventory Management by Lingaya's University, Faridabad in 2010 and Certificate for his Significant Contributions in Operation Management by SREQOM New Delhi in 2009. He received Shiksha Rattan Puraskar in 2007. He is Editor-in-Chief of IJICM and Associate Editor of IJSAEM, Springer and on the editorial board of the IJSS: Operations \& Logistics, IJSOI, and AJOR.

Reena Jain is currently pursuing her Ph.D. in the field of Inventory Management, in the Department of Operation Research, Faculty of Mathematical Sciences, University of Delhi. She has earned dual masters, one in Operational Research from the Department of Operational Research, Faculty of Mathematical Sciences, University Of Delhi and the other in Mathematics from Department of Mathematics, C.C.S. University. She has qualified NET. Her research interest lies in the field of Inventory Management and Supply Chain Management. She has published papers in proceedings of ICPQROM and International Journal of Strategic Decision Sciences. She has published one chapter also in a book "Analytical Approaches to Strategic Decision making Interdisciplinary consideration" published by IGI global.

Mona Verma is working as an assistant professor in Shaheed Sukhdev College of Business Studies, University of Delhi. She has earned her Ph.D. in Inventory 
Management from the Department of Operational Research, Faculty of Mathematical Sciences, University of Delhi. Her research interest lies in the field of Inventory Management and Supply Chain Management. She has publications in many international journals like Revista Investigacion Operacional (Cuba), YUJOR, International journal of Applied Operations Management, International Journal of Logistics and Supply Chain Management, International Journal of Industrial and System Engineering. Some other journals are Opsearch, IJORO, Applied Mathematics and Computation. She has attended many national as well as international conferences. 